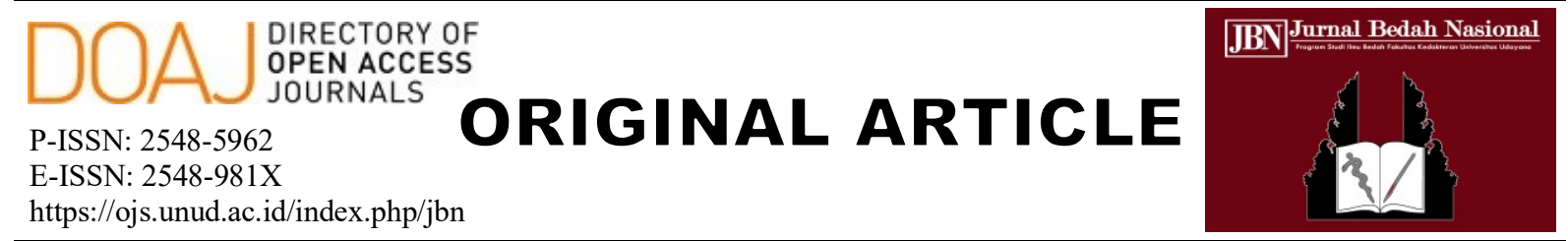

\title{
Hubungan Ekspresi Tumor Infiltrating Lymphocytes dengan Klinikopatologi pada Subtipe Luminal A dan Triple Negative Kanker Payudara di Bali
}

\author{
I Gede Tuban Eling Tulus Widiana ${ }^{1 *}$, Ida Bagus Made Suryawisesa ${ }^{2}$, I Ketut Widiana ${ }^{2}$ \\ ${ }^{1}$ Residen Bedah Umum, Departemen Ilmu Bedah, Fakultas Kedokteran Universitas Udayana / RSUP Sanglah \\ Denpasar. \\ 2 Divisi Bedah Onkologi, Departemen Ilmu Bedah, Fakultas Kedokteran Universitas Udayana / RSUP Sanglah \\ Denpasar.
}

*Penulis korespondensi: elinkholic26@gmail.com.

\begin{abstract}
ABSTRAK
Tujuan: Untuk membuktikan adanya hubungan ekspresi TIL dengan klinikopatologi pada subtipe luminal A dan subtipe TNBC beserta ada tidaknya perbedaan antara kedua subjek tersebut. Metode: Penelitian ini merupakan penelitian observasional, dirancang secara potong-lintang di RSUP Sanglah Denpasar. Kriteria inklusi adalah penderita kanker payudara subtipe luminal A dan subtipe TNBC (triple negative breast cancer) sebagai subjek penelitian. Hasil: Pada penelitian ini terdapat 31 subjek dengan Luminal A dan 40 subyek dengan TNBC. Penelitian ini didapatkan hubungan signifikan antara stadium dengan kadar TIL pada kanker payudara subtipe TNBC $(p=0,01)$. Pada kanker payudara subtipe TNBC stadium tinggi, kemungkinan TIL tinggi 3 kali dibandingkan dengan subjek dengan stadium I-II. Adanya hubungan yang bermakna pada penderita dengan TIL tinggi dengan stadium lanjut pada subtype TNBC dan luminal A ( $\mathrm{p}=0,028$; PR 1,8; 95\%CI 0,54-5,9). Simpulan: Tidak terdapat hubungan signifikan yang diperoleh antara TIL dengan ukuran tumor, stadium klinis, grade histopatologi pada kanker payudara subtipe luminal A maupun TNBC. Tidak terdapat pula hubungan ukuran tumor dan grading tumor antara kanker payudara dengan subtipe TNBC dan luminal A yang memiliki TIL yang tinggi, tetapi terdapat perbedaan pada stadium tumor.
\end{abstract}

Kata kunci: kanker payudara, tumor infiltrating lymphocytes, luminal A, TNBC.

DOI: https://doi.org/10.24843/JBN.2020.v04.i02.p02

\begin{abstract}
Aim: To prove the relationship between TIL expression and clinic-pathology in the luminal A subtype and TNBC subtype along with the presence or absence of differences between the two subjects. Methods: This study was an observational study, designed in a cross-sectional manner at Sanglah Hospital Denpasar. Inclusion criteria were breast cancer patients with luminal A subtype and TNBC (triple negative breast cancer) subtype as research subjects. Results: In this study there were 31 subjects with Luminal A and 40 subjects with TNBC. This study found a significant relationship between stage and TIL levels in breast cancer subtype TNBC $(\mathrm{p}=0.01)$. In high-grade TNBC breast cancer subtype, the possibility of TIL is high 3 times compared with subjects with stage I-II. There was a significant relationship in patients with high TIL with advanced stages in the TNBC subtype and luminal A ( $\mathrm{p}=0.028$; PR 1.8; 95\% CI 0.54-5.9). Conclusion: No significant relationship was obtained between TIL and tumour size, clinical stage, histopathological grade in breast cancer in luminal A and TNBC subtypes. There is also no relationship between tumour size and tumour grading between breast cancer with TNBC subtype and luminal A which have high TIL, but there are differences in tumour stage.
\end{abstract}

Keywords: breast cancer, tumor infiltrating lymphocytes, luminal A, TNBC. 


\section{PENDAHULUAN}

Kanker payudara merupakan penyakit keganasan, bersifat heterogen dan komplek baik dari aspek diagnosis maupun penanganan. Saat ini masih menjadi masalah kesehatan masyarakat dunia. Khususnya pada kaum wanita, kanker payudara menjadi penyebab kematian nomor dua setelah kanker paru.

Angka kejadian kanker payudara merupakan jenis kanker terbanyak didiagnosis pada wanita di wilayah ASEAN dan di dunia pada umumnya. Berdasarkan data Cancer Statistics tahun 2015, ${ }^{1}$ Amerika Serikat mempredikasi angka kejadian kanker payudara sekitar 243.190 kasus baru dengan angka kematian sekitar 40.730 setiap tahun. Berdasarkan data International Agency for Research on Cancer (IARC) tahun 2012, ${ }^{2}$ angka kejadian kanker payudara pada wanita Indonesia 43,3\% dan angka kematian 12,9\% sedangkan di Bali masih belum diketahui secara rinci namun demikian, menurut buletin jendela data dan informasi kesehatan tahun 2013, jumlah kanker payudara di Bali diperkirakan sekitar 1.223 orang. ${ }^{1,3-5}$

Ditinjau dari aspek klinikopatologi dan biologi molekular kanker payudara masih banyak belum diketahui. Perkembangan teknologi dibidang kedokteran seperti immunohistochemistry (IHC) dan microarrays (mammaPrint dan OncoType) maka profil gena (gen profiling) kanker payudara dapat diklasifikasikan menjadi beberapa subtipe berdasarkan status reseptor estrogen dan HER2 yaitu luminal A (ER+ $\mathrm{PR}+$ HER2-), luminal $\mathrm{B} \quad(\mathrm{ER}+\mathrm{PR}+$ HER2+/HER2- Ki67 high), HER2 (HER2+ ER- PR-), dan triple negative (ER- PRHER2-) dengan karakter masing-masing. Kanker payudara secara individu memiliki sifat dan prilaku berbeda - beda, dari tingkat prognosis lebih baik sampai prognosis paling buruk seperti: subtipe luminal A memiliki karakter kurang progresif, kurang respon terhadap kemoterapi tetapi respon terhadap hormonal terapi dengan prognosis lebih baik dibandingkan dengan subtipe lainnya seperti: luminal B, HER2, dan triple negative breast cancer (TNBC). Beberapa faktor dihubungkan dengan prognostik dan prediktif sudah diketahui pada kanker payudara antara lain: status reseptor estrogen (ER/PgR), Her2/Neu, Ki-67, kelenjar getah bening, ukuran tumor, grading histologi, tipe histopatologi, lymphovascular invasion dan kekebalan (imunitas) tubuh. Usia lebih muda cenderung memiliki sifat lebih agresif dan memiliki status reseptor estrogen negatif lebih tinggi, grading histologi tinggi, BRCA-1/2 mutasi, ekpresi HER2, lymphovascular invasion meningkat, dan ekspresi Ki67 tinggi, perilaku seperti ini dihubungkan dengan prognosis lebih buruk. ${ }^{6-8}$

Telah lama dilaporkan hasil penelitian epidemiologi, bahwa pertumbuhan kanker payudara dipengaruhi berbagai faktor diantaranya hormone steroid (estrogen, progesteron, dan androgen), epidermal growth factor (EGF) dan insulin-like growth factor-1 (IGF-1), di mana hormon steroid mempunyai peran utama dalam proses karsinogenesis kanker payudara. Teori diatas secara luas diterima setelah diketemukan estradiol (E2) berikatan dengan reseptor estrogen (ER) membentuk signal transduksi karsinogenesis pada kanker payudara. Epidemiologi data laboratorium melaporkan bahwa karsinogenesis kanker payudara bukan saja dapat disebabkan oleh karena interaksi estrogen dengan reseptor saja, tetapi kerusakan gen dapat terjadi akibat metabolitnya atau non-receptors (genotoxic effects of estrogen metabolites). ${ }^{8,9}$

Sistem imun atau imunitas tubuh salah satu faktor memiliki peran penting dalam proteksi perkembangan kanker payudara. Belakangan ini menjadi perhatian khusus 
bahwa imunitas tubuh berhubungan erat dengan regresi tumor. Sel limfosif $\mathrm{T}$, salah satu imunitas seluler tubuh berperan utama dalam menekan progresi kanker payudara. Migrasi sel limfosit disekitar tumor disebut dengan tumor infiltrating lymphocytes (TIL), telah menjadi isu penting sebagai petanda biologi pada kanker payudara khususnya stadium dini (early breast cancer) dan keberadaan atau ekspresi TIL pada kanker payudara berhubungan dengan prognosis pada subtipe HER2 dan TNBC, kemudian menjadi penting dalam pengembangan imunoterapi pada kanker payudara. International tumor infiltrating lymphocytes (TILs) working group (2014), melaporkan tentang keberadaan TIL pada kanker payudara secara konsisten dapat diukur, sehingga dapat dijadikan langkah rutin dan wajib untuk diperiksa sebelum memberikan terapi, dapat pula dipakai sebagai faktor prognosis dan prediktif pada kanker payudara. Ekspresi TIL dapat menjadi harapan besar untuk menciptakan imunoterapi dengan menghambat sel $\mathrm{T}$ ( $T$ cell checkpoint inhibition). Hallmark of cancer secara luas mengulas tentang betapa pentingnya peran sistem imun untuk mengendalikan sel kanker dan pengembangan terapi target (targeting therapy). ${ }^{10-14}$

Beberapa studi mengatakan bahwa, peningkatan TIL pada tumor primer memiliki nilai prognosis dan prediktif penting pada kanker payudara khususnya pada subtipe TNBC dan HER2, bila terjadi aktifitas sistem imun meningkat pada subtipe TNBC dan HER2, itu menunjukkan prognosis lebih baik dibandingkan dengan aktifitas imunnya menurun. Penelitian case-control menunjukkan bahwa ekspresi TIL tinggi berhubungan dengan grading tinggi, reseptor hormon negatif, HER2 positif, dan multivariat analisis menunjukkan ekpspresi
TIL tinggi sebagai faktor prediktor independen dengan respon komplit patologi (pCR) khusus pada grup HER2. ${ }^{12,15}$

Penelitian lain melaporkan tentang hubungan ekspresi TIL dengan klinikopatologi pada TNBC menunjukkan bahwa, ekspresi tinggi TIL berhubungan dengan ukuran tumor lebih kecil, namun tidak berhubungan secara signifikan dengan grading ataupun stadium. ${ }^{16}$ Penelitian metaanalisis dari 25 studi dengan jumlah sampel 22.000, melaporkan bahwa hasil penelitiannya gagal menunjukkan adanya infiltrasi sel imun berhubungan dengan angka harapan hidup (prognosis) pada semua kasus kanker payudara, tetapi dikatakan ada hubungan dengan ketahanan hidup pada TNBC. Ekspresi CD8 limfosit atau TIL menunjukkan perbaikan terhadap disease free survival (DFS) dan ketahanan hidup kanker payudara tertentu pada semua populasi, sedangkan ekspresi forkhead box protein P3 (FOXP3) limfosit menunjukkan DFS lebih buruk. Penelitian lain (clinical trial) melaporkan bahwa tidak ada hubungan ekspresi TIL dengan grading histopatologi pada TNBC, sedangkan diasumsikan bahwa TNBC memiliki grading tinggi, namun demikian simpulan penelitian ini masih kontroversi yang mana mengatakan bahwa hal ini menjadi bagian respon TNBC terhadap kemoterapi dan subtipe luminal dengan grading rendah, ekspresi TIL rendah, kurang respon dengan kemoterapi, dan hal ini masih belum diketahui dengan pasti. ${ }^{17}$

Studi lain melaporkan tentang hubungan ekspresi TIL dengan komplit respon patologi (pCR) dengan pemberian neoajuvan kemoterapi pada subtipe luminal - HER2 negatif menunjukkan angka kejadian $6 \%$ pada ekspresi TIL rendah, $11 \%$ untuk ekspresi TIL sedang dan 28\% untuk ekspresi TIL tinggi, berbeda dengan subtipe HER2 dan TNBC menunjukkan angka kejadian pCR 
lebih tinggi. Studi tersebut kemudian menginterpretasikan bahwa peningkatan ekspresi TIL mampu memprediksi renpon kemoterapi ajuvan pada semua subtipe kanker payudara dan berhubungan dengan ketahanan hidup lebih baik pada subtipe HER2 dan TNBC. Tetapi sebaliknya peningkatan TIL tidak berhubungan dengan ketahanan hidup pada luminal - HER2 negatif hal itu dikatakan oleh karena adanya perbedaan imuno- biologi pada masing masing subtipe tersebut dan hasil studi ini berpendapat bahwa imunoterapi baik dikembangkan pada subtipe HER2 dan TNBC namun kurang baik pada kanker payudara luminal - HER2 negatif. ${ }^{18}$

Berdasarkan teori dan hasil beberapa penelitian tersebut maka klinikopatologi (ukuran tumor, grading histologi, dan stadium) dan keberadaan ekspresi TIL pada kanker payudara menarik untuk dieksplor lebih mendalam khususnya pada subtipe TNBC dan luminal A. Tujuan studi ini untuk membuktikan adanya hubungan ekspresi TIL dengan kliniko-patologi pada subtipe luminal A dan subtipe TNBC beserta ada tidaknya perbedaan antara kedua subjek tersebut.

\section{METODE}

Penelitian ini merupakan sebuah studi observasional yang dirancang secara potong lintang yang bertujuan untuk membuktikan adanya hubungan ekspresi Tumor Infiltrating Lymphocytes (TIL) dengan klinikopatologi pada kanker payudara subtipe luminal A dan subtipe TNBC beserta ada tidaknya perbedaan antara kedua subjek tersebut. Penelitian ini dilakukan di Departemen Ilmu Bedah Fakultas Kedokteran Universitas Udayana (FK UNUD) / Rumah Sakit Umum Pusat (RSUP) Sanglah, Denpasar, Bali dan di Bagian Patologi Anatomi FK UNUD / RSUP Sanglah, Denpasar, Bali. Pengambilan sampel dan penelitian dilaksanakan dari tahun 2015 hingga 2018, dengan semua pasien kanker payudara subtipe luminal A dan TNBC yang memenuhi kriteria inklusi sebagai populasi terjangkau. Perkiraan besar sampel minimal dihitung menggunakan rumus J.K. Lwanga dan mendapatkan 29 pasien sebagai sampel minimal yang dibutuhkan dalam penelitian ini. Sampel diperoleh secara retrospektif terhadap kasus kanker payudara yang dirawat di bagian bedah onkologi RSUP Sanglah Denpasar dengan menggunakan teknik consecutive sampling kepada populasi penelitian untuk mencapai angka sampel yang dibutuhkan. Kriteria inklusi penelitian ini meliputi: semua penderita yang didiagnosis sebagai kanker payudara dan telah diketahui stadium klinik dan diagnosis histopatologisnya, pasien kanker payudara yang belum mendapat kemoterapi dan radioterapi, serta pasien kanker payudara yang tidak menggunakan kontrasepsi hormonal. Penderita kanker payudara dengan penyakit infeksi, autoimun dan kanker lainnya tidak diikutsertakan, begitu pula pada pasien dengan data klinis dan histopatologi dalam rekam medis yang tidak lengkap.

Seluruh data dan variabel yang dibutuhkan dalam penelitian ini diperoleh melalui catatan medik tertulis. Dari catatan medik dilakukan pencatatan data penderita meliputi keterangan klinis, seperti nama, usia, alamat, staging (TNM), diagnosis histopatologis, grading histologis, imunohistokimia (ER, PR, HER2), riwayat operasi, riwayat kemoterapi, dan radioterapi. Tumor Infiltrating Lymphocytes (TIL) masing-masingnya melalui penilaian histopatologi berdasarkan ada tidaknya dan pola sebaran limfosit pada jaringan tumor kemudian dikelompokkan kedalam dua kategori. TIL dikategorikan tinggi apabila limfosit tersebar merata pada jaringan tumor dan rendah bila infiltrasi limfosit tidak tersebar merata pada jaringan tumor, terjadi fokal atau tidak ditemukan. Data mengenai ukuran tumor, stadium klinis, dan grade histopatologis juga dikumpulkan sebagai 
variabel terikat pada penelitian ini. Ukuran tumor digolongkan kedalam dua kelompok yaitu ukuran tumor kecil apabila besar tumor lebih kecil atau sama dengan $5 \mathrm{~cm}$ dan ukuran tumor besar apabila besar tumor lebih dari $5 \mathrm{~cm}$. Stadium klinis dikelompokkan berdasarkan sistem $\mathrm{T}$ (tumor), $\mathrm{N}$ (nodul), dan M (metastase) menurut AJCC 2009. Kelompok stadium rendah terdiri dari Luminal A dengan stadium 1, Luminal A dengan stadium 2, TNBC dengan stadium 1, dan TNBC dengan stadium 2. Kelompok stadium tinggi terdiri dari Luminal A dengan stadium 3, Luminal A dengan stadium 4, TNBC dengan stadium 3, dan TNBC dengan stadium 4. Grade histopatologis dilakukan berdasarkan gradasi perubahan bentuk dan karakter sel serta arsitektur jaringan yang diperoleh dari sediaan biopsi. Metode yang digunakan adalah semi-kuantitatif berdasarkan Elston \& Ellis dimana grade dibagi menjadi tiga kelompok yaitu grade I, grade II, dan grade III.

Analisis data pada penelitian ini dimulai dengan analisis univariat yang bertujuan untuk menggambarkan karakteristik subjek penelitian dan variabel diteliti. Variabel berskala numerik ditampilkan dalam bentuk rerata dan standar deviasi sedangkan variabel berskala kategorik ditampilkan dalam bentuk frekuensi relatif. Analisis bivariat bertujuan untuk mencari hubungan satu variabel bebas dengan satu variabel tergantung dengan cara membuat tabulasi silang, variabel bebas berada di baris dan variabel tergantung berada di kolom. Tabel silang ditampilkan dalam bentuk baris persenti. Hubungan dinilai dengan beda proporsi atau prevalence ratio. Uji statistik digunakan untuk menilai hubungan bermakna atau tidak dengan $C h i$ Square Test, jika asumsi untuk Chi Square Test terpenuhi, jika tidak digunakan Fischer Exact Test, kemaknaan secara statistik dilihat melalui nilai dengan batas kemaknaan $\mathrm{p}<0,05$.

\section{HASIL}

Selama periode 2015 sampai dengan Desember 2018 terdapat 31 subjek dengan Luminal A dan 40 Subjek dengan TNBC dilibatkan dalam penelitian ini. Rerata umur pada kedua kelompok adalah 48,7 $\pm 8,16$ tahun, di mana 49,9 $\pm 6,74$ tahun untuk luminal A dan 47,78 \pm 9,09 tahun untuk grup dengan TNBC. Ditinjau dari ukuran tumor, terlihat bahwa kedua grup didominasi oleh subjek-subjek dengan ukuran tumor yang besar (T4) dengan proporsi $72,5 \%$ pada grup Luminal A dan 64,8\% pada kelompok TNBC. Ditinjau dari segi stadium, terlihat bahwa proporsi stadium III-IV lebih banyak terdapat pada subjek dengan kanker payudara tipe TNBC dibandingkan dengan luminal A. Hal yang menarik terlihat pada proporsi ekspresi Ki-67. Pada kelompok Luminal A, seluruh subjek ditemukan memiliki ekspresi Ki-67 yang rendah sementara pada kelompok TNBC, didapatkan proporsi 3:1 antara proporsi subjek dengan Ki-67 tinggi berbanding dengan rendah (75\% : 25\%). Ditilik dari derajat TIL cenderung lebih tinggi pada TNBC dibandingkan luminal A (80,6\% dan 50\%). Gambaran karakteristik sampel penelitian dapat dilihat pada Tabel 1.

Pada hasil studi ini, oleh karena baik data variabel dependent dan independent merupakan data nominal atau ordinal, maka analisis bivariat pada bagian ini dilakukan dengan menggunakan uji chi-square atau Fisher's Exact bilamana syarat uji chi-square tidak dipenuhi. Analisis dilakukan dengan menggunakan kelompok re-grouping guna menghindari terjadinya nilai exprected yang terlalu rendah $(<5)$.

Studi ini menunjukan bahwa kelompok dengan TIL tinggi menunjukkan proporsi ukuran tumor yang hampir sama (50\%). Tidak ada hubungan signifikan antara TIL tinggi dan rendah terhadap ukuran tumor pada kanker payudara subtipe luminal A $(\mathrm{p}=0,638$; Tabel 2). 
Tabel 1. Karakteristik Dasar Subjek Penelitian.

\begin{tabular}{lccc}
\hline Karakteristik & Total (\%) & TNBC (\%) & Luminal A (\%) \\
\hline Umur & $48,7 \pm 8,16$ tahun & $47,78 \pm 9,09$ tahun & $49,9 \pm 6,74$ tahun \\
Ukuran Tumor (T) & & & \\
$\quad$ T1-2 & $22(31)$ & $11(27,5)$ & $11(35,5)$ \\
T3-4 & $49(69)$ & $29(72,5)$ & $20(64,5)$ \\
Stadium & & & \\
$\quad$ Stadium I-II & $38(53,5)$ & $24(60)$ & $14(45,2)$ \\
$\quad$ Stadium III-IV & $33(46,5)$ & $16(40)$ & $17(54,8)$ \\
Grade Histologis & & & $13(32,5)$ \\
$\quad$ Grade I-II & $37(52,1)$ & $24(77,4)$ & $27(67,5)$ \\
$\quad$ Grade III & $34(47,9)$ & $7(22,6)$ & \\
TIL $\quad$ & & $20(50)$ \\
$\quad$ Rendah & $45(63,4)$ & $25(80,6)$ & $20(50)$ \\
$\quad$ Tinggi & $26(36,6)$ & $6(19,4)$ & \\
\hline
\end{tabular}

Tabel 2. Analisis Bivariat Hubungan antara Derajat Tumor Infiltrating Limfosit dengan Ukuran Tumor pada Kanker Payudara Subtipe Luminal A.

\begin{tabular}{rcccc}
\hline TIL & T1-T2 (\%) & T3-T4 (\%) & Nilai $\mathbf{~}^{*}$ & PR \\
\hline Tinggi & $3(50)$ & $3(50)$ & \multirow{2}{*}{0,638} & 1,56 \\
Rendah & $8(32)$ & $17(68)$ & & (95\%CI: 0,585-4,17) \\
\hline
\end{tabular}

*Fischer exact PR $=$ prevalence ratio

Table 3. Analisis Bivariat Hubungan antara Derajat Tumor Infiltrating Limfosit dengan Stadium Tumor pada Kanker Payudara Subtipe Luminal A.

\begin{tabular}{rcccc}
\hline TIL & Stadium III-IV (\%) & Stadium I-II (\%) & Nilai p* & PR \\
\hline Tinggi & $2(33)$ & $4(67)$ & \multirow{2}{*}{0,370} & 0,56 \\
Rendah & $15(60)$ & $10(40)$ & & $(95 \%$ CI: $0,17-1,8)$ \\
\hline
\end{tabular}

*Fischer exact PR $=$ prevalence ratio

Tabel 4. Analisis Bivariat Hubungan antara Derajat Tumor Infiltrating Limfosit dengan Grade Tumor pada Kanker Payudara Subtipe Luminal A.

\begin{tabular}{ccccc}
\hline TIL & Grade III (\%) & Grade I-II (\%) & Nilai p* & PR \\
\hline Tinggi & $1(17)$ & $5(83)$ & \multirow{2}{*}{1,000} & 0,69 \\
Rendah & $6(24)$ & $19(76)$ & & $(95 \%$ CI: $0,1-4,74)$ \\
\hline *Fischer exact; PR $=$ prevalence ratio & & &
\end{tabular}

Kelompok dengan TIL tinggi kebanyakan TIL tinggi dan rendah terhadap grade tumor menunjukkan stadium I-II (67\%) Tidak ada pada kanker payudara subtipe luminal A hubungan signifikan antara TIL tinggi dan ( $p=1,000$; Tabel 4).

rendah terhadap stadium tumor pada kanker Secara deskriptif, mayoritas subjek dengan payudara subtipe luminal A ( $\mathrm{p}=0,370$; Tabel subtipe kanker payudara TNBC yang 3). memiliki TIL tinggi menunjukkan stadium

Dalam studi ini, kelompok dengan TIL yang lebih tinggi dan grade III. Ukuran tinggi kebanyakan memunjukkan grade I-II tumor memiliki proporsi yang hampir sama. (83\%). Tidak ada hubungan signifikan antara Pada kelompok kanker payudara subtipe 
luminal A yang memiliki TIL tinggi, Tidak ada hubungan signifikan antara TIL mayoritas menunjukkan stadium tinggi dan tinggi dan rendah terhadap grade tumor pada grade yang lebih tinggi. Ukuran tumor juga kanker payudara subtipe TNBC ( $\mathrm{p}=0,077$; memiliki proporsi yang hampir sama.

Tabel 5).

Kelompok dengan TIL tinggi kebanyakan menunjukkan ukuran tumor T3-4 (60\%).

Tabel 5. Analisis Bivariat Hubungan antara Derajat Tumor Infiltrating Limfosit dengan Ukuran Tumor pada Kanker Payudara Subtipe TNBC.

\begin{tabular}{ccccc}
\hline TIL & T1-T2 (\%) & T3-T4 (\%) & Nilai $\mathbf{p}^{*}$ & PR \\
\hline Tinggi & $8(40)$ & $12(60)$ & \multirow{2}{*}{0,077} & 2,67 \\
Rendah & $3(15)$ & $17(85)$ & & $(95 \%$ CI $0,825-8,602)$ \\
\hline${ }^{*}$ Chi Square; PR = prevalence ratio & & &
\end{tabular}

Tabel 6. Analisis Bivariat Hubungan antara Derajat Tumor Infiltrating Limfosit dengan Stadium Tumor pada Kanker Payudara Subtipe TNBC.

\begin{tabular}{ccccc}
\hline TIL & Stadium III-IV (\%) & Stadium I-II (\%) & Nilai $\mathbf{p}^{*}$ & PR \\
\hline Tinggi & $12(60)$ & $8(40)$ & \multirow{2}{*}{0,01} & 3,00 \\
Rendah & $4(20)$ & $16(80)$ & & $(95 \% \mathrm{CI}: 1,16-7,73)$ \\
\hline
\end{tabular}

*Chi Square; PR = prevalence ratio

Tabel 7. Analisis Bivariat hubungan antara Derajat Tumor Infiltrating Limfosit dengan Grade Tumor pada Kanker Payudara Subtipe TNBC.

\begin{tabular}{ccccc}
\hline TIL & Grade III (\%) & Grade I-II (\%) & Nilai p* & PR \\
\hline Tinggi & $14(70)$ & $6(30)$ & \multirow{2}{*}{0,736} & 2,00 \\
Rendah & $7(35)$ & $13(65)$ & & $(95 \%$ CI: $1,03-3,88)$ \\
\hline
\end{tabular}

*Chi Square; $\mathrm{PR}=$ prevalence ratio

Tabel 8. Hubungan TIL Tinggi antara Klinikopatologi TNBC dan Luminal A.

\begin{tabular}{ccccccc}
\hline TIL tinggi & \multicolumn{2}{c}{ Ukuran tumor } & \multicolumn{2}{c}{ Stadium tumor } & \multicolumn{2}{c}{ Grade tumor } \\
& T1-2 & T3-T4 & III-IV & I-II & III & I-II \\
\hline & & & & & & \\
TNBC & $8(40 \%)$ & $12(60 \%)$ & $12(60 \%)$ & $8(40 \%)$ & $14(70 \%)$ & $6(30 \%)$ \\
Luminal A & $3(50 \%)$ & $3(50 \%)$ & $2(33 \%)$ & $4(67 \%)$ & $1(17 \%)$ & $5(83 \%)$ \\
Nilai p* & 1,000 & 0,028 & 0,054 \\
PR & 0,8 & 1,8 & 4,2 \\
& $95 \%(\mathrm{CI} 0,305-2,09)$ & $95 \%(\mathrm{CI} 0,54-5,9)$ & $95 \%(\mathrm{CI} 0,69-25,72)$ \\
\hline
\end{tabular}

*Fischer exact PR $=$ prevalence ratio

Kelompok dengan TIL tinggi kebanyakan tinggi 2,25 kali dibandingkan dengan subjek memunjukkan stadium tumor III-IV (60\%). dengan stadium I-II (PR 2,25; 95\%CI 1,19Analisis statistik menunjukkan hubungan 4,23; Tabel 6).

signifikan antara stadium dengan kadar TIL Kelompok dengan TIL tinggi kebanyakan pada kanker payudara subtipe TNBC memunjukkan grade tumor III (70\%). $(\mathrm{p}=0,01)$. Pada kanker payudara subtipe Analisis statistik menunjukkan tidak TNBC stadium tinggi, kemungkinan TIL hubungan signifikan antara grade dengan 
kadar TIL tinggi dan rendah pada kanker payudara subtipe TNBC ( $p=0,736$; Tabel 7).

Studi ini menunjukkan adanya hubungan yang bermakna antara TIL tinggi dengan stadium antara TNBC dan luminal A $(p=0,028)$ secara statistik. Namun, secara klinis, perbandingan subjek kanker payudara tipe TNBC dan luminal A dengan TIL tinggi yang memiliki stadium lanjut tidak berbeda (95\% CI mencakup angka 1). Subjek kanker payudara tipe TNBC dengan TIL tinggi cenderung menunjukkan stadium yang 1,8 kali lebih tinggi dibandingkan dengan subjek kanker payudara tipe luminal A, dimana $60 \%$ pasien kanker payudara stadium III-IV memiliki subtype TNBC, dibandingkan hanya $33 \%$ dengan subtipe luminal A. Hubungan TIL tinggi antara klinikopatologi TNBC dan luminal A dapat dilihat pada Tabel 8.

\section{DISKUSI}

Kanker payudara masih dianggap sebagai salah satu permasalahan kesehatan yang krusial secara global pada populasi wanita. ${ }^{2}$ Namun demikian, di negara berkembang dimana keterbatasan sumber daya manusia maupun alat-alat masih merupakan permasalahan, peningkatan prognosis yang dialami masih kurang optimal jika dibandingkan dengan negara-negara maju. Memprediksi prognosis pada kanker payudara masih menjadi tantangan tersendiri bagi klinisi di Indonesia. Hal ini dikarenakan mayoritas kanker yang terdiagnosis sudah memasuki stadium lanjut (stadium III-IV) seperti yang telihat pada karakteristik dasar variabel pada penelitian ini. ${ }^{19}$ Penelitianpenelitian pada dua dekade terakhir memperlihatkan banyaknya temuan-temuan yang berpotensi sebagai prediktor prognosis. Salah satu prediktor yang telah banyak ditelaah adalah tumor infiltrating lymphocyte (TIL) yang merupakan pemeriksaan patologi rutin pada banyak jenis kanker solid. . $^{13,15,20}$
Tumor infiltrating lymphocyte (TIL) sering dianggap mencerminkan respon imun inang terhadap tumor ganas. Sistem imun adaptif diketahui memainkan peran utama dalam kontrol perkembangan tumor pada berbagai jenis kanker. ${ }^{21}$ Signifikansi klinis TIL pada kanker payudara masih kontroversial. Ghebeh $\mathrm{dkk}^{22}$ menunjukkan bahwa infiltrasi limfosit CD4+ dan CD8+ yang tinggi telah dikaitkan dengan status kelenjar getah bening positif dan kelangsungan hidup keseluruhan yang lebih buruk tetapi pada penelitian lain oleh Macchetti dkk. ${ }^{23}$ menemukan hal yang sebaliknya. Hal ini bisa disebabkan karena belum ada konsensus baku untuk menganalisis hitung TIL, di mana TIL dapat dihitung dari stromal dan intratumoral. ${ }^{13} \mathrm{TIL}$ intratumoral didefinisikan sebagai limfosit yang berada pada lingkungan sel tumor dengan kontak sel ke sel. TIL stroma adalah limfosit yang terletak disekitar tumor, tetapi tidak secara langsung berinteraksi dengan sel tumor. ${ }^{13}$

Dalam beberapa penelitian, TIL dikaitkan dengan klinopatologi ganas dan reaktivitas tumor yang tinggi. Semakin tinggi stadium, proses imunosurveilans memicu sel T CD8+, sel $\mathrm{T}$ CD4+ untuk mengeliminasi sel-sel ganas. Dalam penelitian ini, ditemukan hubungan yang signifikan antara TIL tinggi dengan stadium tinggi. Tumor yang lebih agresif memiliki dinamika pertumbuhan tumor yang lebih cepat sehingga area nekrotik lebih luas, kerusakan stroma lebih luas, dan terjadi peningkatan jumlah sel CD4+ dan FOXP3+. ${ }^{24}$ Di sisi lain, beberapa penelitian lain menunjukkan malah semakin tinggi TIL, stadium semakin rendah karena TIL sudah mensupresi TNM tumor. ${ }^{11}$ Penelitian Gunawan dkk. ${ }^{16}$ melaporkan tentang hubungan ekspresi TIL dengan klinikopatologi pada TNBC menunjukkan bahwa, ekspresi tinggi TIL berhubungan dengan ukuran tumor lebih kecil, namun tidak berhubungan secara signifikan dengan grading ataupun stadium. Penelitian meta- 
analisis dari 25 studi dengan jumlah sampel subjek kanker payudara tipe TNBC dengan 22.000, melaporkan bahwa hasil TIL tinggi cenderung menunjukkan stadium penelitiannya gagal menunjukkan adanya yang lebih tinggi dibandingkan dengan infiltrasi sel imun berhubungan dengan angka subjek kanker payudara tipe luminal A, harapan hidup (prognosis) pada semua kasus dimana $85,7 \%$ pasien kanker payudara kanker payudara, tetapi dikatakan ada stadium III-IV memiliki subtipe TNBC, hubungan dengan ketahanan hidup pada dibandingkan hanya 7,7\% dengan subtipe TNBC. Ekspresi CD8 limfosit atau TIL luminal A.

menunjukkan perbaikan terhadap DFS dan ketahanan hidup kanker payudara tertentu pada semua populasi, sedangkan ekspresi FOXP3 limfosit menunjukkan DFS lebih buruk. Penelitian lain (clinical trial) melaporkan bahwa tidak ada hubungan ekspresi TIL dengan grading histopatologi pada TNBC, sedangkan diasumsikan bahwa TNBC memiliki grading tinggi, namun demikian simpulan penelitian ini masih kontroversi yang mana mengatakan bahwa hal ini menjadi bagian TNBC respons dengan kemoterapi dan subtipe luminal dengan grading rendah, ekspresi TIL rendah dan kurang respon dengan kemoterapi, hal ini masih belum diketahui dengan pasti. ${ }^{17}$

Perbedaan dengan penelitian ini bisa disebabkan karena tidak ada stratifikasi grading jenis sel kanker payudara. Padahal, pada penelitian ini ditunjukkan tidak ada hubungan TIL dengan grading. Hal ini juga dapat menjadi pertimbangan selanjutnya untuk melakukan penleitian membedakan stadium tinggi yang memiliki sel kanker dengan diferensiasi baik atau buruk. Penelitian ini merupakan penelitian yang menganalisa secara khusus TIL dan efeknya terhadap tiga parameter klinikopatologis penting (ukuran tumor, stadium dan grade histologis) pada dua subtipe kanker payudara yakni Luminal A dan TNBC. Ditilik dari perbandingan karakteristik dasar, terlihat perbedaan yang nyata pada beberapa aspek diantara kedua subtipe tersebut. Perbedaan yang paling nyata terlihat pada parameter stadium. Proporsi TIL tinggi juga didapatkan lebih tinggi pada TNBC dibandingkan dengan Luminal A. Pada penelitian ini,

Temuan-temuan pada karakteristik dasar ini sejalan dengan aspek teoretis subtipe Luminal A dan TNBC. $^{25}$ Luminal A merupakan subtipe dengan tingkat malignansi terendah pada kanker payudara dan memiliki prognosis yang cenderung baik. Sebaliknya, TNBC merupakan subtipe yang paling malignant dan prognosis penderita cenderung buruk walaupun telah menjalani reseksi. Variabilitas pada TIL juga dapat dijelaskan dari uraian di atas. Subtipe Luminal A merupakan subtipe dengan beban mutasi terendah dan secara keseluruhan masih memiliki pola molekuler yang sama dengan sel luminal normal. ${ }^{26,27}$ Sebaliknya, TNBC memiliki beban mutasi sebanyak dua kali lipat dari Luminal A sehingga lebih banyak memiliki neoantigen yang dapat menginduksi respon imun antikanker. ${ }^{26,28}$ Selain itu, instabilitas genomik juga sering ditemukan pada TNBC yang semakin meningkatkan tingkat mutasi serta apoptosis yang meningkatkan paparan neoantigen ke antigen-presenting cell (APC). Kedua hal ini menjelaskan perbedaan proporsi TIL pada Luminal A dan TNBC pada penelitian ini dimana Luminal A cenderung memiliki TIL derajat positif rendah sementara TNBC memiliki kecenderungan ke arah positif sedang.

TIL merupakan infiltrasi limfosit ke dalam jaringan tumoral yang umumnya menandakan adanya respon imun anti kanker. ${ }^{28}$ Limfosit dan sel NK merupakan dua sel terpenting pada respon ini, namun respon awal anti kanker selalu dimulai dari sel-sel penyaji antigen yang dikenal dengan nama Antigen Presenting Cell. ${ }^{28,29}$ Secara teoretis, semakin 
besar beban mutasional kanker, maka semakin banyak neoantigen yang dimiliki yang dihasilkan oleh mutasi-mutasi yang dialami oleh kanker tersebut sehingga semakin besar repon imun yang dihasilkan. ${ }^{30}$ TIL yang tinggi pada TNBC juga dapat dijelaskan karena TNBC memiliki tingkat mutasi lebih tinggi dibandingkan dengan tumor non-TNBC. TNBC memiliki lingkungan mikro imun khusus. Subtipe TNBC ditemukan memiliki sel $\mathrm{T}$ regulator FOXP3+ (Treg) paling tinggi dibandingkan dengan jenis BC lainnya. PD-1 atau PD-L1 sebagai kofaktor reseptor Treg juga lebih cenderung positif dan lebih tinggi pada pasien TNBC (70\% dan 25\%) atau PD-L1 (59\% dan 33\%) jauh lebih tinggi di antara pasien TNBC. ${ }^{31}$ Tingginya tingkat mutasi dimiliki oleh subtipe TNBC menyebabkan tingkat imunogenitasnya meningkat atau bertambah kuat dan kemudian diikuti dengan peningkatan TIL. ${ }^{5,20}$

\section{SIMPULAN}

Telah banyak studi yang mempelajari dan meneliti mengenai hubungan eskpresi Tumor Infiltrating Lymphocytes dengan klinikopatologi pada kanker payudara baik subtipe luminal maupun TNBC. Namun begitu, hasil yang diperoleh masih sangat bervariasi. Berdasarkan penelitian ini, kami dapat menyimpulkan bahwa tidak terdapat hubungan signifikan yang diperoleh antara Tumor Infiltrating Lymphocytes dengan ukuran tumor, stadium klinis, grade histopatologi pada kanker payudara subtipe luminal A maupun TNBC. Tidak terdapat pula hubungan ukuran tumor dan grading tumor antara kanker payudara dengan subtipe TNBC dan luminal A yang memiliki Tumor Infiltrating Lymphocytes yang tinggi, tetapi terdapat perbedaan pada stadium tumor.

Berdasarkan analisis ini, maka kami berharap studi terkait berikutnya dapat mengevaluasi survivabilitas subjek yang diteliti disini sehingga dapat disinkroniasi temuan asosiasi TIL dengan aspek klinikopatologis dengan survivabilitas pasien. Disamping itu, diperlukan penentuan pengambilan TIL secara peritumoral atau intratumoral pada kanker payudara untuk mengevaluasi asosiasi hubungan ekspresi TIL dengan klinikopatologi dengan luminal A dan TNBC.

\section{UCAPAN TERIMA KASIH}

Penulis mengucapkan terimakasih kepada berbagai pihak yang telah membantu selama pelaksanaan penelitian dan penyusunan artikel publikasi.

\section{PERNYATAAN}

Penulis menyatakan tidak ada konflik kepentingan dalam laporan ini.

\section{DAFTAR PUSTAKA}

1. Seigel RL, Miller KD, Jemal A. Cancer Statistics, 2015. CA Cancer J Clin. 2015;65: 5-29.

2. International Agency for Research on Cancer (IARC). Cancer Fact Sheets: Breast Cancer, Estimated Incidence, Mortality, And Prevalence Worldwide In 2012. World Health Organization [serial online] 2016 [diakses 26 Agustus 2019]. Diunduh dari: https:/gco.iarc.fr/today/data/pdf/factsheets/cancers/cancer-fact-sheets-15.pdf.

3. Kimman M, Norman R, Jan S, dkk. The Burden of Cancer in Member Countries of the Association of Southeast Asian Nations (ASEAN). Asian Pac J Cancer Prev. 2012;13:411-20.

4. Primadi O, Budijanto D, Kurniasih N, dkk. Buletin Jendela Data dan Informasi Kesehatan. Jakarta: Bakti Husada Kementrian Kesehatan RI; 2015. 
5. Shah D, Osipo C. Cancer stem cells and HER2 positive breast cancer: The story so far. Genes Dis. 2016;3:114-123.

6. Goldhirsch A, Wood WC, Coates AS, dkk. Strategies for subtypes-dealing with the diversity of breast cancer: highlights of the St Gallen International Expert Consensus on the Primary Therapy of Early Breast Cancer. Ann Oncol. 2011;22:1736-47.

7. Goldhirsch A, Winer EP, Coates AS, dkk. Personalizing the treatment of women with early breast cancer: highlights of the St Gallen International Expert Consensus on the Primary Therapy of Early Breast Cancer. Ann Oncol. 2013;24:2206-23.

8. Dai X, Li T, Bai Z, dkk. Breast Cancer intrinsic subtype classification, clinical use and future trends. Am J Cancer Res. 2015;5:2929-43.

9. Ladoire S, Arnould L, Apetoh L, dkk. Pathologic Complete Response to Neoadjuvant Chemotherapy of Breast Carcinoma Is Associated with the Disappearance of Tumor-Infiltrating Foxp3+ Regulatory T Cells. Clin Cancer Res. 2008;14:2413-20.

10. Hanahan D, Weinberg RA. Hallmarks of cancer: the next generation. Cell. 2011;144:646-74.

11. Loi S. Host Antitumor Immunity Plays a Role in the Survival of Patients with Newly Diagnosed Triple-Negative Breast Cancer. J Clin Oncol. 2014;32:2935-7.

12. Gingras I, Azim HA, Ignatiadis M, dkk. Immunology and Breast Cancer: Toward a New way of Understanding Breast cancer and Developing Novel Therapeutic Strategies. Clin Adv Hematol Oncol. 2015;13:372-82.

13. Salgado R, Denkert C, Demaria S, dkk. The evaluation of tumor-infiltrating lymphocytes (TILs) in breast cancer: rcommendations by an international TILs
Working Group 2014. Annals Oncol. 2015;26:259-71.

14. García-Teijido P, Cabal ML, Fernández IP, dkk. Tumor-Infiltrating Lymphocytes in Triple Negative Breast Cancer: The Future of Immune Targeting. Clin Med Insights Oncol. 2016;10: 31-9.

15. Yamaguchi R, Tanaka M, Yano A, dkk. Tumor-infiltrating lymphocytes are pathologic predictors for neoadjuvant chemotherapy in with breast cancer. Hum Pathol. 2012;43:1688-94.

16. Gunawan IP. Hubungan Antara Tumor Infiltrating lymphocytes dengan Gambaran klinikopatologis pada Pasien Triple negative breast cancer di Bali (tesis). Denpasar: Universitas Udayana Denpasar; 2015.

17. Barnes TA, Amir E. HYPE or HOPE: the prognostic value of infiltrating immune cells in cancer. $\mathrm{Br} J$ Cancer. 2017;117:451-60.

18. Denkert C, von Minckwitz G, DarbEsfahani S, dkk. Tumour-Infiltrating lymphocytes and prognosis in different subtypes of breast cancer: a pooled analysis of 3771 patients treated with neoadjuvant therapy. Lancet Oncology. 2018;19: 40-50.

19. Komite Penanggulangan Kanker Nasional. Panduan Penatalaksanaan Kanker Payudara. Jakarta: Kementrian Kesehatan Indonesia; 2016.

20. Ahn SG, Jeong J, Hong S, dkk. Current Issues and Clinical Evidence in TumorInfiltrating Lymphocytes in Breast Cancer. $J$ Pathol Transl Med. 2015;49:355-63.

21. Oble DA, Loewe R, Yu P, dkk. Focus on TILs: prognostic significance of tumor infiltrating lymphocytes in human melanoma. Cancer Immun. 2009;9:3.

22. Ghebeh H, Barhoush E, Tulbah A, dkk. FOXP3+ Tregs and B7-H1+/PD-1+ T 
lymphocytes co-infiltrate the tumor tissues of high-risk breast cancer patients: Implication for immunotherapy. $B M C$ Cancer. 2008;8:57.

23. Macchetti AH, Marana HR, Silva JS, dkk. Tumor-infiltrating CD4+ T lymphocytes in early breast cancer reflect lymph node involvement. Clinics (Sao Paulo). 2006;61:203-8.

24. Ben-Shoshan J, Maysel-Auslender S, Mor A, dkk. Hypoxia controls CD4+, CD25+ regulatory $\mathrm{T}$-cell homeostasis via hypoxia-inducible factor-1alpha. Eur $J$ Immunol. 2008;38:2412-8.

25. Viale G. The current state of breast cancer classification. Ann Oncol. 2012;23:x207-10.

26. Budczies J, Bockmayr M, Denkert C, dkk. Classical pathology and mutational load of breast cancer - integration of two worlds. J Pathol Clin Res. 2015;1:225-38.

27. Bianchini G, Balko JM, Mayer IA, dkk. Triple-negative breast cancer: challenges and opportunities of a heterogeneous disease. Nat Rev Clin Oncol. 2016;13:674-90.

28. Li Z, Song W, Rubinstein M, dkk. Recent updates in cancer immunotherapy: a comprehensive review and perspective of the 2018 China Cancer Immunotherapy Workshop in Beijing. J Hematol Oncol. 2018;11: 142.

29. Schumacher TN, Schreiber RD. Neoantigens in cancer immunotherapy. Science. 2015;348: 69-74.

30. Kandoth C, McLellan MD, Vandin F, dkk. Mutational landscape and significance across 12 major cancer types. Nature. 2013;502: 333-9.

31. Gatalica Z, Snyder C, Maney T, dkk. Programmed Cell Death 1 (PD-1) and Its Ligand (PD-L1) in Common Cancers and Their Correlation with Molecular Cancer Type. Cancer Epidemiol Biomarkers Prev. 2014;23: 2965-70. 